\title{
IMRE VÖRÖS*
}

\section{The EU's Constitutional Treaty-Its Development, Structure and Containt}

\begin{abstract}
The study analyses two questions: the necessity of a European Constitution, and the basic content of the European Constitutional Treaty (with the aim to analyse in a separate study the potential effects of the Treaty on the Hungarian Constitution and its application by the Hungarian Constitutional Court).
\end{abstract}

Keywords: European constitution, TEU, TEC

\section{Introduction}

Though the rejection of the Treaty on the European Constitution in two member states' referenda serves as a serious warning sign to all political decisionmakers, this issue must be separated from the scientific value that the Treaty generated and represents. This marks the politically attainable compromise at the level of the European Union today, and it could make the EU's operation more transparent and democratic, and would end the confusion surrounding competencies. At the same time it could lay the constitutional, "public administrative-institutional" and substantive law foundations for a new EU that progresses in a clearly staked out direction and also carries the possibility of a new quality of integration.

The French and Dutch referenda rejecting the Treaty were not about the above considerations: the European Constitutional Treaty has to be regarded as the communis opinio that will be unavoidable in the future, as it is considered a significant achievement both in political and scientific terms. Exploring the Constitutional Treaty-as the most recent "swallow" of European law-and its effect on the Hungarian constitutional order is therefore both practical and useful, even if this swallow has "not made a summer" (yet).

1. The European Constitutional Treaty appears to be the result of a fairly recent process-but here the appearance is deceiptive. It is true that the $29^{\text {th }}$

Scientific adviser, Institute for Legal Studies of the Hungarian Academy of Sciences, H-1014, Budapest, Országház u. 30.

E-mail: vörös@jog. mta.hu 
October 2004 signing of the Treaty establishing a Constitution for Europe (TCE) was preceded by the establishment of a European Convention based on the European Council's December 2001 Laeken Declaration, and that the TCE's draft took on its final form on $10^{\text {th }}$ July 2003, thanks to the Convention's rather intensive work. Valéry Giscard d'Estaing, the president of the Convention, presented the final product to the Italian Presidency-in-office. The Intergovernmental Conference beginning on $4^{\text {th }}$ October 2003 debated the draft and then adopted it, and finally the TCE was signed on $9^{\text {th }}$ October 2004 in Rome.

Were only a mere 22 months necessary for working out and passing the TCE? Obviously not. European law, especially European constitutional law, the science of public administration and political sciences have all worked over a decade in preparation of the signing, creation and designing of the TCE.

2. Already since the early 1990s a whole series of scholarly as well as practice-oriented conferences have focused on the necessity of creating a European constitution. Nothing illustrates the urgency of the problem better than the fact that the Charter of Fundamental Rights was designed before the TCE, so its text simply had to be inserted into the TCE. This process was also reinforced by the fact that member states' constitutional courts (especially the German and Italian courts), encountered the problem of securing fundamental rights with increasing urgency, which-as I will analyse in more detail below-in turn brought up with growing urgency the issue of the relation between member states' constitutions and European law, in other words the question of primacy.

3. It is impossible to make even a passing reference to each of the innumerable conferences and scientific as well as non-scientific communiqués issued on this subject. Let me just allude to the fact that in addition to the scientific analyses the European Parliament adopted a decision on $10^{\text {th }}$ February 1994 (,,Resolution on the Constitution of the European Union”). ${ }^{1}$ In this decisionwhich interestingly (even surprisingly), the 518 member Parliament adopted with an unconvincing majority (155 in favour, 87 opposed, 46 abstentions)the Parliament refers to its ,repeated" request: the European Union needs a democratic constitution. In this context the decision noted with satisfaction that the Committee on Institutional Affairs had come up with a Draft Constitution for the European Union.

From the scientific side a body called the European Constitutional Group presented its own draft constitution, ${ }^{2}$ but other groups, too, prepared expertises and drafts. ${ }^{3}$

' Document A3-0064/94. OJ C 61, 10. 02. 1994. 155-170. February 10. O. J. 1994.

2 A Proposal for a European Constitution. Report by the European Constitutional Group. London, 1993. 
In 2001 the reputed T.M.C. Asser Institute in the Hague organised a conference which, looking into the future, focused on the impending enlargement, the accession of the 10 new Central Eastern European states and in this context also the issue of the European Constitution. ${ }^{4}$

In 2002 a broad analysis entitled „Europäisches Verfassungsrecht” was published ${ }^{5}$-to mention an arbitrarily selected example-which in part presents the theoretical dogmatic foundations of European constitutional law, and in part offers a perspective on future developments. The theoretical-dogmatic foundations touch upon complex issues of the constitutional legislator, federalism, the institutions, sovereignty and the primacy of Union law, European constitutional jurisdiction, the EU's and the EC's constitutional relations, Union citizenship, basic rights, the economic constitution and the unusual term "competition-constitution" (Wettbewerbsverfassung). The future outlook analyses such basic issues as the problem of an EU situated at the intersection of the community's and the member states' legal systems, the legal structure of the EU as an association of states (Staatenverbund), and finally the prospective advantages of a European Constitution.

\section{On the need for a European constitution}

1. It has been communis opinio for quite a while now that the current Treaty establishing the European Community (will be referred to as TEC below) and the Treaty on European Union (TEU), are no longer sufficient as the constitutional foundations of Union co-operation; instead of a "treaty-based constitution" there is a need for a real European constitution.

The notion of a "treaty-based constitution" refers to the fact that the EU does have a constitution already: the two Treaties, the Treaty on European Union (TEU), and the Treaty establishing the European Community (TEC). Based on the these two treaties the European Court of Justice (ECJ) has drawn out of the Community law those constitutional safeguards and constitutional principles based on which Community law began to function as constitutional

3 The Shaping of a European Constitution. Report of the Working Group on the European Constitution. 1990; Kind, P.-Bosco, A. (eds.): A Constitution for Europe. London, 1991.

${ }^{4}$ Kellerman, A.-Jaap W. de Zwaan, Czuczai, J. (eds.): EU Enlargement. The Constitutional impact at EU and National Level. The Hague, 2001.

${ }^{5}$ von Bogdandy, A. (ed.): Europäisches Verfassungsrecht [European Constitutional Law]. Heidelberg, 2003. 
law. In the ECJ's application of law the TEC veritably began to fulfil the role of a constitutional charter. In the Court's practice Community law began taking on the functions of a de facto constitution in terms of determining the relationship between member states and their citizens, as the Court interpreted (and on this basis applied) constitutional safeguards "into" their relationship with the EC.

2. The basis for providing safeguards to citizens/individuals was especially the direct effect of Community law which opened up the possibility of enforcing individual rights in the courts. We refer to safeguards such as rule of law („Etat de droit”, „Rechtsstaat”): in its prominent and often-cited Les Verts decision $^{6}$ the Court proclaimed that the requirement for rule of law was a foundation of the EC. Rule of law means that community or member state measures adopted in the EC must be in harmony with the EC's ,basic constitutional charter, the Treaty" (i.e. the TEC). Deriving them from the member states' constitutions, the ECJ recognised such principles as the fundamental components of the rule of law, as for instance due process the prohibition of discrimination, the defence of legitimate expectations the prohibition of retroactive effect, the requirement of proportional limitations and good faith in procedures

In addition to demanding the rule of law the ECJ also explicated the separation of powers, democratic governance, the right to judicial and the defence of fundamental rights, as well as defence of the four freedoms of the market as constitutional values. ${ }^{7}$ The specialised literature refers to this process as the ,constitutionalisation" of Community law, at the same time pointing out that this is something different from the emergence of a nation state's burgeoning constitution. Wechsler, for instance, refers to the TEC's gradual, step-by-step, verdict-by-verdict transformation into a sui generis constitution by virtue of the ECJ's application of it. ${ }^{8}$

3. Naturally this has its own story-as do the books, too (,habent sua fata libelli"). The crystallisation of European constitutional principles in no small measure emerges amidst the concerned „frowning" of member states' constitutional courts.

3.1. The question arose in the context of how to interpret the primacy of European law in relation to the member states' legal systems, especially

${ }^{6}$ Case 294/83, Les Verts, [1986] European Court Review, 1339, 1365.

7 See for example. Petersmann, E.-U.: Proposals for a New Constitution for the European Union: Building-Blocks for a Constitutional Theory and Constitutional Law of the EU. Common Market Law Review, 1995, 1124.

${ }^{8}$ Wechsler, B.: Der Europäische Gerichtshof in der EG-Verfassungswerdung [The European Court of Justice in the Genesis of the EC Constitution]. 1995. Cited in: Petersmann: op. cit. 1142. 
constitutions and the constitutional rights and principles safeguarded by those.

The Italian ${ }^{9}$ and German ${ }^{10}$ constitutional courts both voiced their objections to the absolutist interpretation of the primacy of Community law which held that the latter is above the whole of the national member states constitutions, not only above a significant portion of the constitutional rules and the other internal legal regulations.

3.2. The Italian Constitutional Court pointed to the limits of the priority of Community law-as laid down and expounded by the European Court of Justice-set by the Italian constitution. In its Frontini verdict the court emphasised that even though overall Community law might be above the Italian constitution, it certainly does not enjoy primacy over the constitution's provisions regarding the inalienable rights of individuals and the constitution's fundamental principles. Though Art. 11 of the Italian constitution does regulate the possibilities of transferring or limiting competencies, but at the same time the abovementioned fundamental rights and principles serve as „,counterweights” and „counterlimits” (controlimiti) to this constitutional option.

In the Fragd decision ( $21^{\text {st }}$ April 1989) the constitutional court reserved its right to review some regulations of Community law with regards to their compatibility with certain human rights articles of the Italian constitution. ${ }^{11}$

3.3. The German Federal Constitutional Court similarly asserted that Community law does not have absolute primacy with respect to certain fundamental rights protections enshrined in the German Basic Law-as long as Community law does not offer a similar measure of protections; the constitutionality of Community law will be reviewed with respect to the standards laid down by the Grundgesetz (the German constitution). In its famous Solange I verdict the Federal Constitutional Court stated that the Grundgesetz's fundamental law guarantees enjoy priority as "as long as (solange) the competent organs of the Community have not removed the conflict of norms"... between Community

9 On the primacy of community law see: Várnay, E.- Papp, M.: Az Európai Unió joga [The Law of the European Union]. Budapest, 2005. 82. For the decisions of Italian constitutional court see: de Witte, B.: Constitutional Aspects of European Union Membership in the Original Six Member States: Model Solution for the Applicant Countries? In: EU-Enlargement. op. cit.74.

${ }^{10}$ For the "Solange" decisions see for example BverfGE 73, 339. The most recent relevant decision is: BverfG, 2 BvL 1/97. Europäische Zeitschrift für Wirtschaftsrecht. 2000. 702. For the Maastricht decision see. BVerfGE 89, 155. Also see: Várnay-Papp: op. cit. 307-312.

${ }^{11}$ Gaja, G.: New Developements in a Continuing Story: The Relationship between EEC Law and Italian Law. Common Market Law Review, 1990, 83. 
law and the basic law safeguards contained within the Grundgesetz "in accordance with the Treaty mechanism". This means that the Community law's primacy is not unconditional, absolute primacy, but merely conditional. In the 1986 Solange II decision the Federal Constitutional Court observed with relief: given the European Commission's practice regarding human rights and general level of the protection of fundamental rights, the introduction of direct elections to the European Parliament, as well as the fact that all member states joined the European Convention on Human Rights, it finds the situation satisfactory "....as long as (solange) the European Communities, and in particular the case law of the European Court, generally ensure, an effective protection of fundamental rights as against the sovereign powers of the communities which is to be regarded as substantially similar to the protection of human rights required unconditionally by the Grundgesetz..." The Federal Constitutional Court will not make use of its powers in the sense of deciding upon the applicability of secondary community legislation by member states' courts with reference to the German Grundgesetz. In other words the Federal Constitutional Court found that the situation that had emerged (unlike the situation at the time of the Solange I decision) bore no probability of a conflict of norms Community law and the constitutional, especially fundamental right safeguards of the Grundgesetz.

3.4. In de Witte's interpretation these statements denote the thesis of relative primacy of Community law over member states' constitutions and thus they deny the notion of absolute primacy.

4. En route towards the "constitutionalisation” of Community law a crucial stepping stone was marked by the assertion of the TEU Art. 6 (2) that the EU respects fundamental rights. In the instance the TEU refers to the European Convention on Human Rights, the general principles of Community law, as well as to member states' common constitutional traditions.

4.1. In view of the above it cannot be regarded as a coincidence, but rather as a significant step in the coherent process of development that the EU decided on drafting its own Charter of Fundamental Rights. Nonetheless, this was not always an obvious choice: the drafting of the Charter was accompanied by doubts.

4.2. The question that arose was whether drafting a European Charter of Fundamental Rights would in fact increase citizens' fundamental rights as compared to the current situation? The answer was not unequivocal. In Weiler's poignant analysis ${ }^{12}$ the Europeans are becoming nauseated by the protection of

${ }^{12}$ Weiler, J.: Europe 2000-The Constitutional Agenda. An Outline. In: EU Enlargement. op. cit. 10. 
fundamental rights: they are protected by the member states' constitutional and regular courts, by the European Convention on Human Rights and its European Court of Human Rights in Strasbourg and by the European Commission. The Commission stated already in 1969 that it finds all community measures that infringe upon the member states' common constitutional tradition unacceptable. Thus primarily one would have to clarify the legal policy goals of such a charter; its undeniable advantage would be that it would make comprehensible and tangible even for the "man of the streets" what so far only jurists-and even among those only a select group-sense and understand. For this very reason Weiler thinks that the creation of the charter might backfire. It could offer a loophole to avoid undertaking anything in this area, in other words it would merely offer an excuse to evade taking necessary steps. In reality the European Community does not have a human rights and fundamental rights policy and that is the real problem. What is needed is not the formalisation of rights, but the formulation of a policy for the enforcement and institutionalisation of fundamental rights.

The best counterexample to this is community competition policy. Arts 8182 of the TEC provide the basis of community competition law and therein the guarantee of the internal market's unity. Obviously these articles would be hardly more than rhetoric if the Directorate General No. 4 were not engaged in enforcing these rules. In fact since the introduction of EC Regulation 1/2003-as is well-known-with the decentralisation of the enforcement of competition law the member states' competition authorities (European Competition Network$\mathrm{ECN}$ ) and courts have also become involved in implementing the provisions of the two articles.

The situation regarding fundamental rights is similar: it is hardly possible to rely on the courts in this area, as the continuous monitoring of violations, the gathering of information, conducting inquiries or potential ,investigations” cannot be a task for the courts, but has to be within the purview of an organisation established for this purpose.

4.3. Similarly, we must also face up to the fact that from a functional perspective the ECJ's current institutional/organisational system is not completely capable of enforcing fundamental rights. Though the ECJ's justices are excellent jurists, few are constitutional lawyers per se. The real problem stems from the fact-and this is where the shadow of new „Maastricht decisions" looms-that it may be within the context of an ECJ decision that the primacy enjoyed by European law over even the most important fundamental rights, and the associated principles and rules guaranteed by member states, are enforced. This, the total subordination of member states' basic law regulation to European law, is problematic and may substantially violate member 
states' constitutional „sensibilities”. In the final analysis, Weiler ${ }^{13}$ points outthe ECJ's relation to the member states' courts is rather a lot more complex and of a different nature than the legal standing of the House of Lords or the US Supreme Court in the respective countries' constitutional order. ${ }^{14}$ Weiler thus concludes that a separate European constitutional court would be necessary, which could exclusively address issues of constitutional law and thus concentrate on those without dividing its attention among complex internal market, economic, competition law, etc., problems, among which constitutional jurisdiction would be only one of several issues.

4.4. As is commonly known the body charged with drafting the Charter worked out its proposal under the chairmanship of Roman Herzog, formerly president of the German Constitutional Court and then German head of state, and presented its Charter of Fundamental Rights which the intergovernmental conference at Nice accepted on 7th December 2000. In the process of drafting the TCE the Charter of Fundamental Rights was then integrated into the document as its Part II.

5. The „constitutionalisation” of Community law could therefore be regarded as a process taking place under a kind of member state compulsion.

The primacy of Community law cannot be enforced absolutely, if for instance basic law safeguards are insufficient; its relativity on the other hand opens the door to those objections-as formulated in the abovementioned Italian and German constitutional court statements-that primacy exists only in so far as Community law provides the same level of protection as member states' constitutions do. If this is not the case, then constitutional courts reserve the right to potentially declare-according to their own constitutional standards-certain provisions of Community law unconstitutional, thus effectively ordering lower courts in the given member state not to apply it. It is obvious that this line of reasoning implies a judicial review of Community law by the constitutional courts of member states: in effect these bodies can „destroy” Community law depending on whether it is consistent with their own constitution; in this case Community law will not enjoy primacy in the given member state.

The EU was thus under pressure to act: drafting a European constitution including safeguards of fundamental rights became inevitable. ${ }^{15}$

${ }^{13}$ Ibid. 8 .

${ }^{14}$ Ibid. 8.

${ }^{15}$ Gordos, Á.-Ódor, B.: Their book entitled Az Európai Alkotmányos Szerződés születése [(The Birth of the European Constitutional Treaty). Budapest, 2004.] offers useful information on the circumstances of the European Constitution's creation without the difficult dogmatic background above, and also provides a wealth of information on the 
6. Still, the debate on the necessity of a constitution continued to rage in 2001. On the one hand the phenomenon referred to as ,democratic deficit”, the lacking legitimacy, was indisputable, as was apparent that the Treaties could not function as real constitutions. The Treaties were too detailed, frequently overlapping, while at the same time from a constitutional legal standpoint they were not differentiated enough. Ultimately, the Union's competencies can only be limited-that is obstacles to the indefinite expansion of these competencies can only be erected-by the way of a constitution.

6.1. Even in light of the above, there was still controversy surrounding the question of whether it was really necessary to formally create a separate, newly worded constitution to address these issues. (An ironic reference comes from Weiler, who titles one of the sections in his study „Does Europe Need a Constitution?", while casting doubt on the idea in the next section's title: „Does Europe really need a Constitution?"16). Weiler believes that a formal constitution would also introduce a formal legislative hierarchy that would deprive European constitutional development of the very advantage that stems from its essence, its peculiar feature deriving from singular historical circumstances: flexibility. The democratic deficit and other problems ought not to be necessarily addressed by drafting a constitution. It would be sufficient to separate the TEU's and TEC's constitutional parts par excellence, while preserving the non-constitutional parts as „,normal” Community law.

6.2. The fundamental challenge that nonetheless needs to be addressed constitutionally is the question of proportion between intergovernmentalism and supranationalism. In reality this is the basic issue underlying the institutional reform proposals of successive intergovernmental conferences. Developing the $E U$ is a rather paradox process. Wouters, for instance, sees a shift towards the intergovernmental feature at the expense of supranationalism. In his opinion the Council of Ministers continues to gain ground at the expense of the Commission, a case in point is the memorable participation of an extremist party in the Austrian conservative-led government, when the diplomatic measures taken by the Union were not handled by the Commission, but outside the institutional structure of the EU. ${ }^{17}$

6.3. Even though it is possible to argue with the observation above, the issue of intergovernmentalism/supranationalism was always-and presumably

Hungarian government's position on the relevant issues, as well as the work of the Hungarian representatives at the convention.

${ }^{16}$ Weiler: op. cit. 5.

${ }^{17}$ Wouters, J.: Institutional and Constitutional Challenges for the European UnionSome Reflections in the Light of the Treaty of Nice. In: EU Enlargement... op. cit. 45. 
will be in the foreseeable future-one of the basic questions of the EU's development strategy. The magic word can probably be found in the dichotomy of increasing democratic legitimacy versus efficient functioning. In this context Wouters points to possibilities such as the appointment of ECJ justices. This is a sensitive issue that no matter how far it strays from the abovementioned "magic word" is still inseparably tied to it: it is an indication of lacking democratic legitimacy that there is no democratic control over the appointment process and thus it is impossible to guarantee that a judge inducted into the body will fulfil all the conditions laid down in TEC Art. 223, in terms of his independence or expertise.

6.4. There is also a lot to be done in terms of the transparency of EU institutions to European citizens. Though the modifications introduced by the Amsterdam Treaty-for instance TEC Art. 255's new text-called for guaranteeing citizens' right of access to documents and other data, in reality the exercise of this right is conditional on general principles, so in practice the right of access is rarely enforced. ${ }^{18}$ In other words the exceptions need to be narrowed and the exercise of this right needs to be expanded. The ECJ played an important role in this area (as well)-especially in the Netherlands $v$. Commission case ${ }^{19}$-in the "constitutionalisation" of European law. This case and the ECJ's practice are good examples illustrating how the ECJ fits the member states' common constitutional traditions into the EU's constantly evolving "constitutional law."

6.5. The abovementioned democratic legitimacy/democratic deficit and the associated problems of rule of law, the more precise demarcation of competencies and the issue of re-evaluating the role of member states' parliaments all contributed a great deal to the TCE's drafting.

6.5.1. Democratic legitimacy fares best in the co-decision procedure. Still, this is the area where the most demands for progress came in. Wouters specifically called attention to the possibility that the European Parliament's role ought to be increased: the Nice Treaty, for its part, did not ensure parallel to the introduction of the qualified majority voting in the Council that it would also be tied to a co-decision procedure, or at least that there would be the possibility of obligatory consultation for the European Parliament. ${ }^{20}$ There is no such requirement for the fiscal policy or monetary rules concerning the euro zone, nor for trade in intellectual property. The situation is even worse as far as the second pillar is concerned, though somewhat better in the third.

\footnotetext{
${ }^{18}$ Wouters: ibid. 45.

${ }^{19}$ Case C-58/94 Netherlands v. Council [1996] European Court Review, I-2169.

${ }^{20}$ Wouters: op. cit. 48.
} 
6.5.2. The question of rule of law also raises concerns that provided important arguments in favour of drafting and adopting the TCE. The ECJ in its previously mentioned Les Verts decision and in subsequent decisions emphasised that if we consider the EC or the EU to have rule of law, then this implies-in fact assumes-that there is a system of legal remedies and procedures at the Union level, which neither the EU nor the member states can circumvent, in as far as the review of the legality of the Union's own actscompared to Community law-is concerned. ${ }^{21}$ Given that such a requirement implies the comparison of community's and member states' process of legislation with European law, this practically means the formulation of a requirement for constitutional jurisdiction of sorts. Even though-as we have seenthe ECJ has fulfilled this role almost since its inception and has developed European constitutional principles in the process, including especially the enforcement of basic rights, the obligation for implementing the rule of law will evidently necessitate a set of requirements that extend beyond what has been established hitherto. One such question was in how far individuals can turn directly to the ECJ for the purpose of enforcing their rights-the ECJ's stance on the TEC Art. 230's standing rules is arguably too strict in comparison. Obviously this is about fundamental questions the answers to which-given the deeply constitutional and basic rights nature of the issue-cannot be left (even in part) to the ECJ's practice. ${ }^{22}$

6.5.3. Similarly the TCE drafting was also instigated by the need for a more precise demarcation of competencies between the EU and the member states. The multi level governance system appeared worthy of consideration. It implies that responsibility be distributed by domains and tasks, divided between different actors who are connected-while sufficiently preserving and securing their autonomy-by efficient institutional links. ${ }^{23}$

6.5.4. The unsolved issue of the relationship between member states' parliaments and the European Parliament was also raised, of course. This delicate matter naturally did not come up in the context of modifying or reducing the European Parliament's prerogatives in any way. Parliament (TEC Art. 189) consists of representatives of the Community's member states and is thus one of the most efficient repositories of political democracy.

${ }^{21}$ Case 294/83 Les Verts v. Parliament [1986] European Court Review, 1339; also see Case C-2/88 IMM Zwartveld [1990] European Court Review, I-3365.

${ }^{22}$ See for example Wouters: op. cit. 49.

${ }^{23}$ Ibid. 52. 
Suggestions to make Parliament bicameral, ${ }^{24}$ however (it was not hard to detect that the model for this idea stemmed from the German and Austrian federal parliaments), illustrate the problem well in spite of their stunning nature. A second chamber would-in Wouters' opinion-not reduce Parliament's authority, of course, but rather turn the Council of Ministers into some sort of second chamber, the membership of which would consist of representatives from the member states' governments. The practices used in the co-decision procedure demonstrate, however, that the Council of Ministers-at least from a constitutional/theoretical perspective-already works as a kind of second chamber. In such a system the first chamber would be home to directly elected popular representatives, while the second chamber-and here the example of the German/Austrian, even the American federal system is apparent-would represent territorial/regional governmental interests, as a second chamber constituted on a territorial principle.

6.6. It is indisputable that the problems and ideas above, raised merely by the way of example-regardless of how much or in which form they found their way into the TCE-significantly influenced and in some cases and contexts even forced the inclusion of certain ideas into the document.

\section{The TCE's content and its main features}

The TCE consists of a preamble and four parts. These are complemented by 36 protocols and two annexes.

The Preamble and the first two parts are really the TCE's constitutional content.

1.1. Part I-unlike the others-does not have its own title, even though it contains the rules concerning the Union's nature, its self-specification, organisation and operation.

Part I is divided into nine titles: Title I addresses the Union's definition and objectives, Title II recognises fundamental rights and deals with Union citizenship, IV details the institutional framework and bodies of the EU, the fifth title concerns the exercise of the Union's competencies (including the Union's legislative system, the common foreign, security and defence policy, the rule of law, the solidarity of member states and enhanced co-operation), Title VI bears the name „Democratic Life of the Union”, while Title VII addresses finances, VIII good neighbourhood relations, and the final title, number IX dwells on Union membership.

${ }^{24}$ Ibid. 53; See also: Horváth, Z.-Ódor, B.: Az Európai Unió Alkotmánya. [The Constitution of the European Union]. Budapest, 2005. 28. 
1.2. Part II incorporates the Charter of Fundamental Rights adopted earlier.

1.3. Part III deals with Union policies and their operation.

1.4. Part IV contains general and closing dispositions.

The protocols and annexes following the four parts occasionally touch upon very important basic issues, such as the role of national parliaments in the EU, the ECJ's statutes, or the protocol laying down the procedure to be followed in the case of excessive deficits.

2. With respect to its structure the TCE has thus fulfilled expectations: it puts into a well-arranged, clear system...

- the EU's fundamental objectives and values-including the fundamental rights-, its organisational and operational order, as well as

- the EU's policies.

There are two essential areas in which the TCE's content can be grouped.

3. In terms of content the TCE bring changes of great importance: even if its only role had been to formulate-for the first time in the history of European integration-in a generally comprehensive manner the rules in all those areas that the TEU and the TEC address, than it still would have been worth drafting. The overly complex, inscrutable mass of statutes burdened by numerous instances of overlapping primary law is now being replaced by clear regulations that-at least to a certain degree-enable the average citizen to find out what the EU is, if he so wishes.

Selecting any of the many important changes in the TCE is inevitably bound to be arbitrary. Accepting this risk we would like to call attention to the following:

- the EU's basic goals reflect the transition from initial economic integrationthe creation and maintenance of a unified internal market, that is the establishment of a certain level of economic union-to political integration (Art. I-3);

- the TCE proclaims the EU's legal personality (Art. I-7), which simultaneously abolishes the-undeniably complicated, but given the continuously ongoing development inevitable-three pillar structure.

- In this context the TCE also lays down the rules for withdrawing from the Union (Art. I-60)

- it clearly (with the high standards one expects from a real constitution) settles the relations between the EU and member states declaring the equality of member states before the TCE (Art. I-5);

- finally establishes in a written legal statute the primacy of Union law over member state law (Art. I-6) .

- the clear tabulation of the EU's competencies (Title III, Arts I-11-18);

- in a structural/institutional context the TCE establishes the permanent position of an European Council President (I-22), as well as that of a Union Minister for Foreign Affairs (I-28); 
- the TCE achieves a veritable breakthrough with its reform of decisionmaking procedures: it limits the number of those areas in which unanimity is required (in effect curtailing the scope of member state vetoes) and creates the institution of qualified majority, the so-called dual majority, in the decisionmaking process (Art. I-25);

- the TCE gives greater weight to the European Parliament by expanding its competencies (Art. I-46 provides the basis);

- it introduces the institution of popular initiative [Art. I-47 (4)], as a manifestation of participatory democracy;

- the TCE's Part II includes among its constitutional provisions the Charter of Fundamental Rights with its enumerated basic rights-which is absolutely essential for any document aspiring to the rank of a constitution-, thus preempting the abovementioned potential source of friction between the EU and member states' constitutional courts.

4. Though in terms of its legal classification the TCE is a treaty between subjects of international law, and can only be modified with their consent and through consensus, it was nonetheless undoubtedly created with the intention of setting up a constitution.

When we are asked to take a position on the question whether this could be considered a constitution in the traditional constitutional law sense of the word, then it certainly appears to be a waste of words-one might say hairsplitting-to look for the attributes of a nation-states' constitution in this document. This is a unique process in European history whose legal, constitutional representation cannot be undertaken with traditional legal or constitutional categories. Undoubtedly, a traditionally understood constitution would have to talk of a traditionally understood sovereign state and, correspondingly, of the people constituting it, who are the source of said sovereignty. In this context we cannot talk of a state-constituting people-the European people. But this does not imply that the TCE, in its own specific range of tasks, in the very specific, historically determined set of problems it needs to address, could not fulfil the function of a basic law, or to put it better: a „Basic Law”.

The TCE determines the constitutional framework for those fundamental questions that are not handled by primary legislation: the TEU and the TEC, which would be repealed once the TCE takes effect (the Euratom Treaty is the only one that would not be affected by the TCE's potential adoption). The EU is not a "state" in the traditional sense and thus the debate whether it can be made to fit the "confederation of states" or "federal state" mould seems nonsensical. The EU is genuinely a sui generis formation, with the intermediate characterisation ,invented” by the German Federal Constitutional Court (a kind of neither this nor that): the „Staatenverbund”. Correspondingly this non-traditional forma- 
tion of states cannot have a traditionally understood constitution, but it can have a „constitutional treaty" based on an international treaty between the member states.

This peculiarity is well expressed in the compromise name that the document finally received: „Treaty establishing a Constitution for Europe”.

The category and institution of the „treaty-based constitution"-introduced and analysed above (see I.1)-as a living, already practically existing "constitution" (within the conceptual framework outlined above), cannot be immediately replaced by a "real" constitution as it is traditionally understood, with all the regular features of a constitution, for that would require a federal state that is compatible with traditional constitutional law categories. At the current stage of development there is no sign of such a state, however. The TCE's undoubtedly small, but at the same time determined and significant steps in this direction cannot change the fact of lacking sui generis state formation. The "Constitutional Treaty" replacing the "treaty-based constitution" captures the complexity of the integration process, its historically unique nature, even at the level of a wordplay, and it also expresses the notion that in the given situation this "product" best represents the reality of the attainable level of integration-now and in the foreseeable future as well.

In our opinion the TCE therefore-with all its compromises-adequately reflects the current state of economic and political development: the state in which the EU-consisting of economic and political union-is right now and will be in the foreseeable future and medium term.

This is not only no small achievement, but also the attainable maximum-if it is attainable at all in light of the integration process. But not even the TCE itself sees this as the end of the road.

5. The Preamble clearly expresses the nature of the European unification process: Paragraphs (2)-(3)-(4) (,wishes to deepen”; , united ever more closely"; „...continue the work accomplished within the framework of the Treaties establishing the European Communities and the Treaty on European Union, by ensuring the continuity of the Community acquis,") all indicate that integration is on the path of preservation through cancellation. ${ }^{25}$ The TCE's goal is thus not to finally conclude for the long-term a continuously evolving process-and it could not do that even if it wished to do so-but to further develop the results

\footnotetext{
${ }^{25}$ See the TCE's critical analysis in: Czuczai, J.: Some Points Concerning the EU Constitution from a Hungarian Perspective. In: Curtin, D.-Kellermann, A. E.-Blockmans, S. (eds.): The EU Constitution: The Best Way Forward? T. M. C. Asser Institut. The Hague, 2005. 433-445; on the preservation through cancellation: Szigeti, P.: Az Európai Alkotmányszerzödés hatása a Köztársaság Alkotmányára [The European Constitutional Treaty’s Impact on the Constitution of the Republic]. Special edition. 225.
} 
accomplished so that a Union of 25 will be capable of flexibly serving the goal of integration at least in the medium-term.

5.1. Though the TCE was criticised immediately following its adoption for being "overly centralised", the truth is that it preserves the intergovernmental nature of the development process-the TCE is an international treaty that can only be amended unanimously, based on a consensus of all member states. The Preamble [Paragraph 4] talks of a Europe "United in diversity", making clear that unified Europe is based on the preservation of the member states' national identity [Preamble Paragraph 3].

These are not just the typical generalities common in preambles: Part I, Title I, Art. I-1-that is the TCE's first rule on establishing the Union-clearly states the EU's competencies are derived from the member states who confer on the Union their own competencies, which in turn practices it on a "Community basis".

5.2. The second notion in the Preamble is the strengthening of democracy and transparency in the EU's public life-and the TCE does indeed live up to these expectations.

5.3. The Preamble finally refers to the values that the EU subscribes to and then later details in Part I Title I Art. I-2: the TCE begins with a commitment to the values of human rights, democracy, equality and the rule of law. These values are complemented in Art. I-2 by the individual rights of persons belonging to minority communities, pluralism, a general prohibition of discrimination, tolerance, social justice, solidarity, as well as the declaration of gender equality.

6. The TCE's "individual" boundaries are set by the fact that the European Union established by this Treaty (Art. I-1) is successor to the current EU and the EC (Art. IV-438). Correspondingly, with the taking effect of the TCE, the TEU and the TEC are repealed, as are the Accession Treaties. Separate detailed rules regulate the issue of territorial scope.

7.1. In addition to the EU's aforementioned values we also find the summary rules concerning the EU objectives here - many of which we have already encountered in the context of the TEC introductory regulations. One such goal is, for instance, the well-being of its peoples. Aside from such general statements we also find a statement on the "two unions": Art. I-3 (2) includes among the Union's objectives the notion that the EU is an area with both, political union (without internal frontiers, with freedom, security and justice), and economic union (an internal market where competition is free and undistorted). These two constitute the real EU, the summary term for which is the "European Union". 
The common feature of the two partial unions is that they seek to realise a social market economy, promoting social solidarity, economic and social cohesion and solidarity between the member states.

7.2. It is important to point out that the TCE puts a great deal of emphasis on the rule of law, as one of the fundamental attributes of the EU: up to Art. I3 this category is mentioned thrice, in the Preamble, in Art. I-2, and in Art. I-3, (2) listing the EU objectives. It is obvious here that this is not merely the TEU, the TEC or the acquis which "show up again", but the member states' common constitutional traditions as well. The text's emphasis, however, is to set fundamental conditions concerning potential future enlargements, which-due to their safeguard character-(rightly) raise the bar very high for potential new member states and candidate countries (Romania, Bulgaria, Croatia, but especially Turkey). Though as an aside one could point out that there are sources of law that not only fail to satisfy these requirements but-we shall return to this below-straight-out contradict them.

7.3. The clear, comprehensible repetition of the four freedoms is-finally!mentioned together with the prohibition of discrimination.

7.4. Art. I-5 of the TCE states another well-known proposition: the principle of member state's obligation to co-operate [Art. I-5, (2)], but this is preceded by the statement on the equality of member states before the "Constitution"this is how the TCE refers to itself at this point!-, as well as the respect for their national identities [Paragraph 1].

7.5. Art. I-6 finally declares the primacy of Union law: what this means is the primacy of the law "adopted by the institutions of the Union in exercising competences conferred on it" over the legal order of the member states. The TCE does not mention the relationship between its own provisions and the member states' constitutions-leaving this "thorny delicacy" to the member states' constitutional legislators. As is known, the Republic of Hungary has significant outstanding debts in this area-the primacy of European law over the Hungarian Constitution ought to finally laid down in the Constitution. Unless this happens the issue cannot be regarded as concluded. We will return to this issue further below, as with the TCE's potentially entry into force settling this long-delayed question may become completely inevitable for the Hungarian constitutional legislator. ${ }^{26}$

\footnotetext{
${ }^{26}$ For further information see: Vörös, I.: Az EU-csatlakozás alkotmányjogi: jogdogmatikai és jogpolitikai aspektusai [The constitutional, legal dogmatic and legal policy aspects of EU accession]. Jogtudományi Közlöny, 57 (2002) 397; Kecskés, L.: Magyarország EU-csatlakozásának alkotmányossági problémái és a szükségessé vált alkotmánymódosítás folyamata. [The constitutional problems of Hungary's EU accession and the
} 
7.6. Art. I-7 declares the EU's legal personality, thus the Union become a subject of international law.

7.7. Title II of Part I, referring to the Charter of Fundamental Rights contained in Part II, recognizes basic rights-with two clarifications. On the one hand the TCE additionally also refers to the European Convention on Human Rights, as well as the common constitutional tradition of member states. This means that in applying and interpreting the Charter of Fundamental Rights-the TCE's Part II-these two legal texts have to be considered.

The fundamental rights, if properly applied and interpreted, are therefore part of the Union's legal order.

What this means is that in applying Union law one always has to pay attention to fundamental rights, as those constitute the fundament of the whole European legal order as its core principles. In our opinion their classification as core principle means that Part II, containing the fundamental rights, on the one hand also incorporates concrete applicable measures, and on the other hand-as supplementary feature in the case of loopholes, for instance-is also a repository of general principles that ought to be considered when applying European law. The basic rights are therefore the lex generalis of European legal order, which influence the application and interpretation of any lex speciali.

7.8. The TCE's beneficial effect is inestimable in the sense that it subsumes the first two of the three effective treaties (TEU, TEC, Euratom Treaty), in a single "treaty", thus repealing them (the Euratom Treaty is not affected by the TCE). The Treaty on the European Coal and Steel Community (ECSC Treaty) lapsed on $23^{\text {rd }}$ July 2002 as the fifty years its validity had been envisioned for had expired, but the majority of its provisions live on in the TEC. ${ }^{27}$

This means that the EU's primary law becomes codified in a single document, which marks a fundamental change in terms of its effects. The European legal order, the EU's structure, institutions and operations have become transparent, clearer and more easily comprehensible. This is reinforced by Art. IV-438 which pronounces succession: the successor of the EU and the EC established by the TEU is the EU established by the TCE:

The situation of secondary law is different: those remain in force. The same applies for other elements of the acquis, as well as the ECJ's and the Court of First Instance's decisions, which continue to preserve their source of law character.

process of the constitutional amendments necessitated thereby]. Európai Jog, 2003/ Nos. 1 and 3., 21-30. and 22-23.

${ }^{27}$ See Horváth-Ódor: Az Európai Unió Alkotmánya. op. cit. 58. 
8. The TCE brings significant changes: simplification and increased transparency in the system of sources of law. Title I Chapter I talks of the Union's legal acts within the framework of "Common Provisions", and significantly simplifies the extremely complex, nigh inscrutable system. The TCE's articles I-33-I-39 introduce four legally binding and two legally non-binding so-called legal acts. Dogmatically it is odd that the TCE does not refer to the legislative system but to "acts", and it is odder still that it distinguishes between legally binding and non-binding acts. It would be a substantial error if the text were to talk about legally non-binding sources of law, but the designations of "acts" benevolently conceals the dogmatic slip-up. We return to the problem later to analyse its effect on the Hungarian constitution.

A legally binding act is the European law (which corresponds to the current first pillar regulation), the European framework law ("successor" to the directive)-these so-called legislative acts [Art. I-33 (1)] have general applicability.

A European regulation differs from legislative acts in that it serves their implementation and thus, depending on which law's implementation it was issued to serve, it could have 'European law' content, that is immediately binding content, or it could have "framework law" content, meaning in essence that it only obliges member states to pursue certain goals but leaves the choice of adequate tools up to them.

The European decision is not necessarily generally, but a binding executive act. A decision can designate specific addressees, and in such a case it is only binding for them.

The TCE preserves the institutions of legally binding recommendations and opinions, but through enshrining them in the constitution it inaugurates them as constitutional institutions. According to the position delineated by the Hungarian Constitution and the Hungarian Constitutional Court this is a very worrisome practice; we will return to our concern about the integration of these institutions into the constitution further below.

9. We will not delve further into the TCE's detailed contents, as the objective of the present study is not to provide a full commentary on the TCE but to assess its likely effects. Beyond the abovementioned effects we will therefore in a separate study concentrate on some specific problems, with special attention to their impact and mutual feedback effects on the Hungarian Constitution and the practice of the Hungarian Constitutional Court. 